\title{
Foraging time allocation in a territorial fish: influence of reproductive activities
}

\author{
John M. Green, Guy Martel \& Elizabeth A. Kingsland \\ Biology Department and Marine Sciences Research Laboratory, Memorial University of Newfoundland, Newfoundland, \\ Canada A1B $3 \times 9$
}

\begin{abstract}
Individual territorial male cunners Tautogolabrus adspersus were observed in the morning and afternoon during pre-spawning, spawning, and post-spawning seasons in Conception Bay, Newfoundland. Male cunners appear to feed at a constant rate throughout all seasons, but they shift their foraging to the morning during the spawning season such that feeding does not conflict with spawning which occurs only in the afternoon. This is viewed as a true optimal foraging strategy, fitness rather than energy intake being the currency maximized (Sih 1982).
\end{abstract}

\section{INTRODUCTION}

Animals and plants can be viewed as input-output systems (Pianka 1976), input being the energy they ingest and output being the progeny they produce. An animal is foraging in an optimal way to the extent that it maximizes its fitness (Pyke et al. 1977, Sih 1982). Foraging strategies are influenced by the characteristics of the food, competitors and predation risks (e.g. Werner \& Hall 1974, Charnov et al. 1976, Milinski \& Heller 1978), and also by the reproductive state of the animal, although there are few studies which have demonstrated the latter (e.g. Hoffman 1983). In this paper we present field evidence that the foraging time allocation of territorial male cunners Tautogolabrus adspersus is influenced by their reproductive activities.

The cunner is a labrid inhabiting North Atlantic coastal waters from Chesapeake Bay to northern Newfoundland (Leim \& Scott 1966) and its basic life-history traits have been described elsewhere (Green \& Farwell 1971, Pottle \& Green 1979a, b). In Conception Bay, Newfoundland, some male cunners establish territories which they defend for their entire active period (early Jun to late Oct). During the spawning season, which lasts from mid-July to the beginning of August, territorial males spawn much more frequently than do non-territorial males (Pottle \& Green 1979a). Spawning is concentrated in late afternoon, as is typical for labrids (Warner \& Robertson 1978), during which pelagic eggs are released following a brief but elaborate courtship (Pottle \& Green 1979a).

Cunners feed mainly on benthic organisms (Chao 1973, Olla et al. 1975, Green et al. 1984), and territorial males sustain themselves from food in their territories. In Newfoundland, cunners do not have any known predator and it is therefore unlikely that predation risks have any influence in shaping foraging strategies of mature individuals.

\section{MATERIALS AND METHODS}

In June, July and August 1980, 7 tagged territorial males were observed morning and afternoon during the pre-spawning, spawning and post-spawning seasons. During each season each fish was observed through snorkelling or with SCUBA for 10 mornings and 10 afternoons as close in time as possible, weather permitting. Each observation period lasted $30 \mathrm{~min}$, during which all the behaviors of a fish were quantified and recorded on an underwater writing pad. A description of these behaviors is given in Pottle \& Green (1979b). For our analyses, all intraspecific aggressive behaviors (chases, approaches, laterals, frontals, gapes and bites) were combined.

Comparisons of the occurrence of different behaviors in territorial males according to season (pre, spawning, post) were treated as a split plot analysis of variance design (Winer 1971) and were analysed with S.A.S. (Helwig \& Council 1979) software. 


\section{RESULTS}

The 3 activities monitored in territorial males: feeding responses, intraspecific aggressions, and courtship behaviors, show significant differences both during the day and seasonally (Table 1). The overall level of feeding responses does not vary significantly from season to season while courtships and aggressions peak during spawning (Table 2).

Because there are significant time-season interactions, a graphical representation of the same behaviors in time over seasons is shown in Fig. 1. Feeding responses occur more often in the morning than in the afternoon only for the spawning season, while courtships and aggressions occur more often during the afternoon than in the morning for the pre-spawning and spawning seasons.

\section{DISCUSSION}

Energetic models often fail to predict patterns in foraging strategies. This may be because, as noted by Sih (1982), one implicit assumption of optimal foraging theory is that some factors affecting fitness (such as predation risks, mating, parental care, etc.) do not affect the foraging strategy. As our results demonstrate, foraging behavior is influenced by social and reproductive considerations. In territorial cunners, the time devoted to social and mating activities is an important determinant of reproductive success (Martel \& Green unpubl.), which we assume to be Iepresentative of inclusive fitness. During the spawning season, when territorial and reproductive activities peak, territorial male cunners shift most of their foraging activities to the morning, a time when spawning and courtships behaviors are least frequent. Shifting of the feeding period is probably necessary so as to reduce the conflict with territorial activities.

At other times of the year (pre and post-spawning), territorial males forage throughout the daylight period. If we assume that each feeding attempt yields on average the same caloric return, our data indicate that males are not restricting the amount of their foraging activity during the spawning season, but rather are shifting the timing of that activity. Based on the number of feeding bouts (not significantly different throughout the seasons), territorial males have fixed

Table 1. Tautogolabrus adspersus. Results of ANOVAs testing the influence of time of day and of season on the distribution of some activities in territorial male

\begin{tabular}{|c|c|c|c|c|c|}
\hline Activity & Source of variation & df & Sum of squares & $\mathrm{F}$ & Significance \\
\hline \multirow{4}{*}{ Feeding } & Time (A.M. or P.M.) & 1 & 635.73 & 42.38 & $<0.001$ \\
\hline & Season & 2 & 66.39 & 2.21 & 0.11 \\
\hline & Time-season interaction & 2 & 317.60 & 10.59 & $<0.001$ \\
\hline & Error & 411 & 6378.41 & & \\
\hline \multirow{4}{*}{ Aggression } & Time (A.M. or P.M.) & 1 & 2864,67 & 31,39 & $<0.001$ \\
\hline & Season & 2 & 3418.97 & 18.73 & $<0.001$ \\
\hline & Time-season interaction & 2 & 2549.60 & 13.97 & $<0.001$ \\
\hline & Error & 411 & 37508.10 & & \\
\hline \multirow{4}{*}{ Courtships } & Time (A.M. or P.M.) & 1 & 1128.49 & 75.70 & $<0.001$ \\
\hline & Season & 2 & 908.64 & 30.40 & $<0.001$ \\
\hline & Time-season interaction & 2 & 569.94 & 19.07 & $<0.001$ \\
\hline & Error & 411 & 6152.89 & & \\
\hline
\end{tabular}

Table 2. Tautogolabrus adspersus. Distribution of activities of territorial males for the 3 sampling periods. Average number of occurrencies per day (A.M. + P.M.) per season for $30 \mathrm{~min}$ observation periods (see text). Student-Newman-Keuls tests are used (significance at $\mathrm{P}<0.005$ )

\begin{tabular}{lcccc|}
\hline Activity & Pre-spawning & Spawning & Post-spawning & Significance \\
\hline Feeding responses & 2.6 & 3.1 & 2.1 & ns \\
Aggressions & 9.1 & 14.0 & 7.0 & Spawn > Pre > Post \\
Courtships & 1.8 & 4.0 & 0.3 & Spawn > Pre > Post \\
ns = non significant & & & & \\
\hline
\end{tabular}




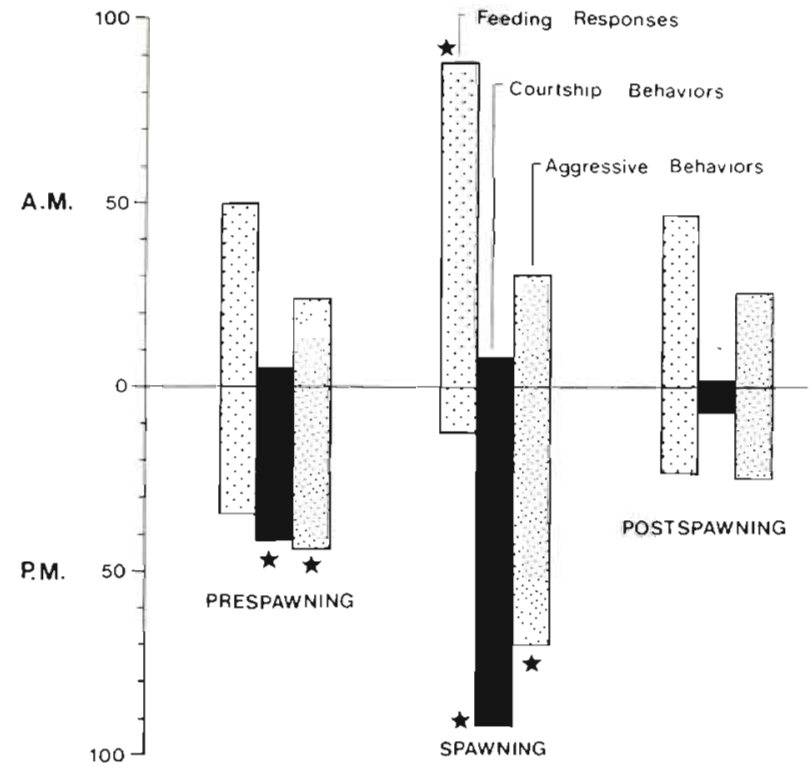

Fig. 1. Tautogolabrus adspersus. Relative distributions of activities of territorial males during morning and afternoon. For each type of behavior, the value during the spawning season is taken to be $100 \%$. Stars: significant difference $(\mathrm{P}<0.01)$ between A.M. and P.M. For feeding responses, $\mathrm{N}=1,102$; for courtship behaviors, $N=838$; for aggressive behaviors, $\mathrm{N}=4,197$

energy requirements, which points towards a timeminimizing strategy (Schoener 1971, Green et al. 1984).

Female cunners, unlike territorial males, forage throughout the day during the spawning season (Green et al. 1984). Females have been observed to spawn more than once per day, but the average courtship-spawning sequence requires less than 4 min (Pottle \& Green 1979a). Hence even a female which spawns several times in a day spends a relatively short period in reproductive activities and is able to spend almost all of her time foraging. Female cunners also differ from territorial males in the amounts and kinds of food items they ingest (Green et al. 1984), apparently ingesting higher energy but less abundant or evenly dispersed prey than territorial males.

Territorial males keep their territories long after the spawning season is over. There are energetic costs associated with this strategy, as indicated by the decreased condition of territorial males relative to females and non-territorial males at the onset of overwintering torpor (Martel 1983). The benefits of territoriality must then be related more to reproduction than to foraging. The shift of feeding activities can thus be considered a true optimal foraging strategy, the currency maximized being inclusive fitness (spawning) rather than energy intake (Sih 1982).

The lack of a diel pattern in either courtship behavior or aggression during the post-spawning sea- son can be attributed more to an overall reduction in frequency than to a shift to the morning. Courtship and aggression are related to territoriality in cunners, which in turn relates ultimately to reproduction (Martel \& Green unpubl.), and these activities are expected to show a decline following the spawning season. Similar peaks in aggression and courtship intensities during the spawning season have been recorded for at least 1 other labrid, Pseudolabrus celidotus (Jones 1981).

This study further emphasizes how behavioral constraints might influence the timing of the foraging activities of animals and the need to incorporate such factors into foraging models.

Acknowledgements. We are grateful to Glen Gilbert and Rick Cunjak who helped with various aspects of the field work. Drs. G. R. Skanes and B. Kim provided advice on statistical matters, and Drs. D. Morris and D. H. Steele reviewed the manuscript. This research was funded by a grant from the National Science and Engineering Research Council of Canada (NSERC) to J.M.G. Contribution 600 from the Marine Sciences Research Laboratory.

\section{LITERATURE CITED}

Chao, L. N. (1973). Digestive system and feeding habits of the cunner, Tautogolabrus adspersus, a stomachless fish. Fish. Bull. U.S. 71: 565-585

Charnov, E. L., Orians, G. H., Hyatt, K. (1976). Ecological implications of resource depression. Am. Nat. 110: 247-259

Green, J. M., Farwell, M. (1971). Winter habits of the cunner, Tautogolabrus adspersus (Walbaum 1792) in Newfoundland. Can. J. Zool. 49: 1497-1499

Green, J. M., Martel, G., Martin, W. D. (1984). Comparisons of the feeding activity and diets of male and female cunners, Tautogolabrus adspersus (Pisces: Labridae). Mar. Biol. 84: $7-11$

Helwig, J. T., Council, K. A. (ed.). (1979). S.A.S. users guide. Statistical Analysis System Institute, Cary, North Carolina

Hoffman, S. G. (1983). Sex-related foraging behavior in sequentially hermaphroditic hogfishes (Bodianus spp.). Ecology 64: 798-808

Jones, G. P. (1981). Spawning-site choice by female Pseudolabrus celidotus (Pisces: Labridae) and its influence on the mating system. Behav. Ecol. Sociobiol. 8: $129-142$

Leim, A. H., Scott, W. B. (1966). Fishes of the Atlantic coast of Canada. Bull. Fish. Res. Bd Can. 155: 269-271

Martel, G. (1983). Sexual selection and territory size in male cunners, Tautogolabrus adspersus, in Conception Bay, Newfoundland. Unpubl. M. Sc. thesis, Memorial University of Newfoundland, St. John's

Milinski, M., Heller, R. (1978). Influence of a predator on the optimal foraging behaviour of sticklebacks (Gasterosteus aculeatus L.). Nature, Lond. 275: 642-644

Olla, B. L., Bejda, A. J., Martin, A. D. (1975). Activity, movements, and feeding behavior of the cunner, Tautogolabrus adspersus, and comparison with young tautog, Tautoga onitis, off Long Island, New York. Fish. Bull. U.S. 73: 895-900 
Pianka, E. R. (1976). Natural selection of optimal reproductive tactics. Am. Zool. 16: 775-784

Pottle, R. A., Green, J. M. (1979a). Field observations on the reproductive behavior of the cunner, Tautogolabrus adspersus (Walbaum) in Newfoundland. Can. J. Zool. 57 : 247-256

Pottle, R. A., Green, J. M. (1979b). Territorial behavior of the north temperate labrid, Tautogolabrus adspersus. Can. J. Zool. 57: 2337-2347

Pyke, G. H., Pulliam, H. R., Charnov, E. L. (1977). Optimal foraging: a selective review of theory and tests. $Q$. Rev. Biol. 52: $137-154$
Schoener, T. W. (1971). Theory of feeding strategies. Ann. Rev. Ecol. Syst. 11: 369-404

Sih, A. (1982). Optimal patch use: variation in selective pressure for efficient foraging. Am. Nat. 120: 666-685

Warner, R. R., Robertson, D. R. (1978). Sexual patterns in the Labroid fishes of the western Caribbean, I: The wrasses (Labridae). Smithson Contr. Zool. 254

Werner, E. E., Hall, D. J. (1974). Optimal foraging and size selection of prey in the bluegill sunfish (Lepomis machrochirus). Ecology 55: 1042-1052

Winer, B. J. (1971). Statistical principles in experimental design. McGraw-Hill, New York

This paper was presented by Professor R. L. Haedrich; it was accepted for printing on April 5, 1985 